\title{
Synthesis and Evaluation of Nicotinic Acid Derived Tetrazines for Bioorthogonal Labeling
}

\author{
Gergely B. Cserép, ${ }^{\mathrm{a}, \dagger}$ Orsolya Demeter, ${ }^{\mathrm{a}, \dagger}$ Effi Bätzner, ${ }^{\mathrm{b}}$ Mihály Kállay, ${ }^{\mathrm{c}}$ Hans-Achim Wagenknecht, ${ }^{* \mathrm{~b}}$ Péter Kele*a \\ ${ }^{a}$ Chemical Biology Research Group, Institute of Organic Chemistry, Research Centre for Natural Sciences, Hungarian Academy of \\ Sciences. Magyar tudósok krt. 2, H-1117, Budapest, Hungary. E-mail: kele.peter@ttk.mta.hu \\ ${ }^{b}$ Institute of Organic Chemistry, Karlsruhe Institute of Technology (KIT), Fritz-Haber-Weg 6, 76131 Karlsruhe, Germany. E-mail: \\ Wagenknecht@kit.edu \\ c MTA-BME "Lendület” Quantum Chemistry Research Group, Department of Physical Chemistry and Materials Science, Budapest \\ University of Technology and Economics, P.O. Box 91, H-1521 Budapest, Hungary \\ †These two authors contributed equally to the work.
}

Received: The date will be inserted once the manuscript is accepted.

\begin{abstract}
A set of nicotinic acid derived tetrazines were synthesized and evaluated for activity in inverse electron demand Diels-Alder (IEDDA) reactions with various dienophiles. It was found that the performance of these tetrazines is governed by two factors. Theoretical and experimental investigations showed that steric effects may override the energetically predicted order of reactivity. Making a compromise between reactivity and stability a selected tetrazine was incorporated into a deoxynucleotide to afford a bioorthogonalized bulding block enabling IEDDA based tagging schemes of nucleic acids.
\end{abstract}

Key words: tetrazine, inverse electron demand Diels-Alder, bioorthogonal, nucleic acid, labeling

Chemical manipulation, e.g. fluorescent tagging of biomolecules by means of inverse electron demand Diels-Alder (IEDDA) reaction between tetrazines and strained ring systems present the fastest bioorthogonal modulation procedure today. ${ }^{1}$ Accordingly, selective and efficient labelling of $\mathrm{DNA}^{2,3}$ and $\mathrm{RNA}^{4}$ was achieved by activated olefins as building blocks, introduced either as phosphoramidites or nucleoside triphosphates. Most recently, it was shown that this type of DNA modification chemistry works also in living cells. ${ }^{3}$ Orthogonality of such IEDDA reactions with other bioorthogonal transformations for example, with strain promoted azide-alkyne cycloaddition (SPAAC) was also examined. ${ }^{5}$ In fact, one-pot dual labeling by IEDDA and copper-catalyzed cycloaddition was already realized for modification of DNA. ${ }^{6}$ Orthogonal modification of biomatter by the same bioorthogonal transformation is also possible. Lemke and co-workers demonstrated that tetrazines with distinct reactivities towards dienophiles enable pulsechase labeling of insulin receptors expressing noncanonical amino acids that harbor different dienophiles. ${ }^{5}$ In this latter report the distinct reactivity of a non-symmetrically and a mono-substituted tetrazine implies the governing effects of the steric demand of the substituents in the proximity of the reaction center.

For our purposes that involve the development of bioorthogonalized oligonucleotides we have sought for new tetrazine derivatives with reasonable reactivities and stability suitable for longer in vivo exposure. Reactivity and stability are two seemingly contradictory properties, and in most cases a compromise is necessary when selecting biorthogonally applicable reagents. Former examples show that the reactivity of tetrazines can be predicted with relatively high fidelity as it is mainly governed by the energy of its frontier molecular orbital (LUMO). ${ }^{7}$ As a rule of thumb, electron withdrawing substituents lower the energy of the LUMO of the tetrazine scaffold therefore increase reactivity. ${ }^{7}$

The presence of pyridine units appending from the tetrazine core is often beneficial for the reactivity of tetrazines towards dienophiles. ${ }^{1,7}$ For its synthetic accessibility, further functionalization and its rate enhancing features, we have chosen nicotinic acid based nitriles to build up activated tetrazine scaffolds. We were also curious of inspecting the effect of steric demand of the substituents on the reaction rate. Therefore we have designed three nicotinic amide modified tetrazines as model compounds in order to evaluate their reactivity towards selected dienophiles (Figure 1).

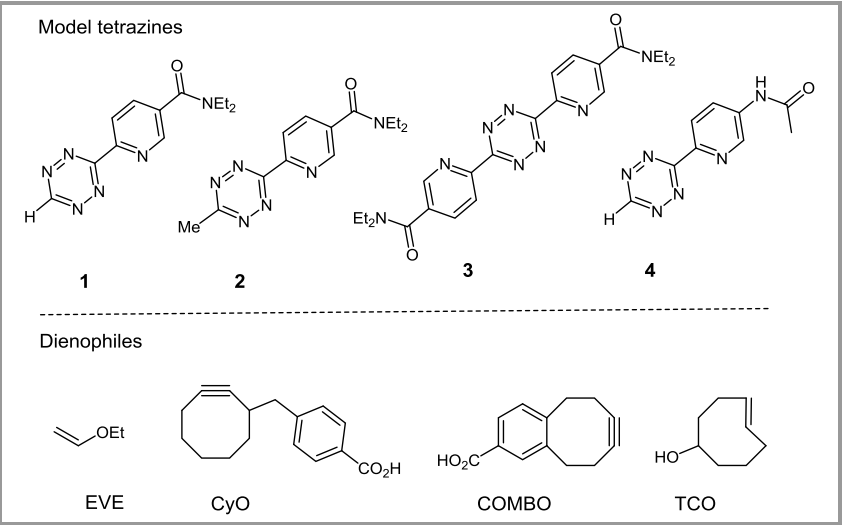

Figure 1 Structure of model tetrazines with different steric demand (top) and dienophiles used in this study (bottom).

The synthesis of monosubstituted tetrazine (1) started with the reaction of 6-cyano- $N, N$-diethylnicotinamide (5) with aqueous hydrazine in the presence of formamidine acetate. The resulting dihydrotetrazine was oxidized directly with isopentyl-nitrite to furnish $\mathbf{1}$ in $42 \%$ yield ( 2 steps). Non-symmetrically substituted tetrazine (2) was made in a similar manner from $\mathbf{5}$ and acetonitrile in the presence of hydrazine-hydrate. The 
primary product dihydrotetrazine was treated with in situ generated nitrous gases to provide $\mathbf{2}$ in an overall $10 \%$ yield. Symmetrically decorated tetrazine (3) was obtained by treating 6-cyano- $N, N$-diethylnicotinamide with hydrazine-hydrate. Subsequent oxidation with nitrous gases yielded 3 in an overall 30\% yield (Scheme 1).

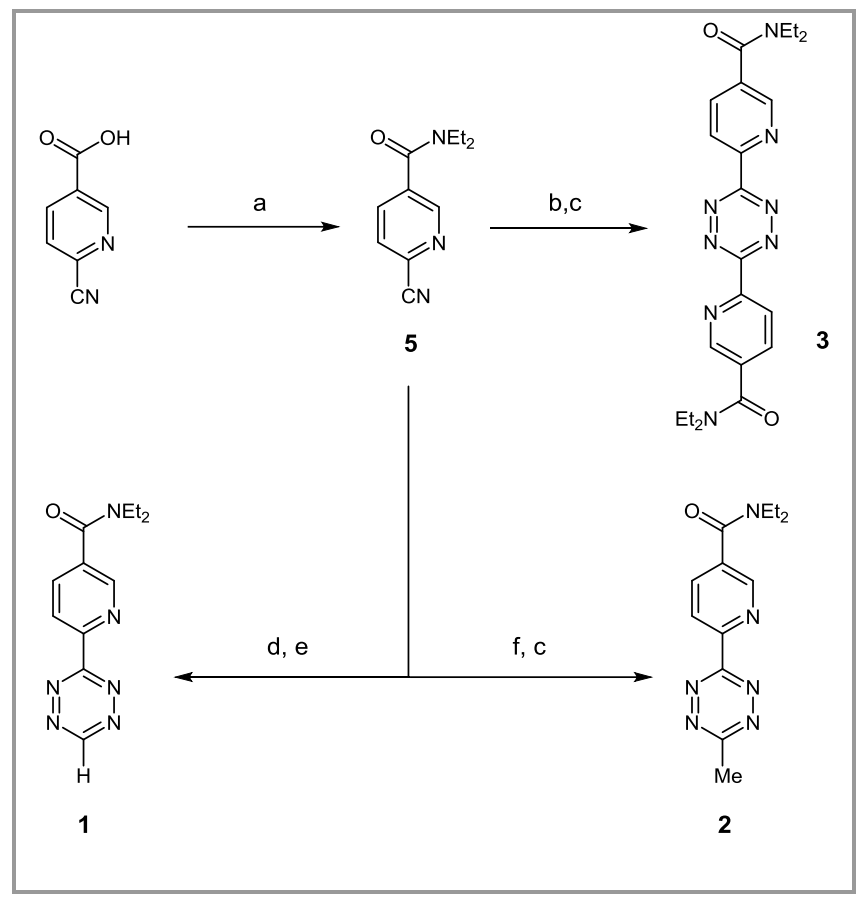

Scheme 1 Synthesis of model tetrazines. a) $\mathrm{HNEt}_{2}, \mathrm{HOBt}$, HBTU, DIPEA, THF, r.t. $16 \mathrm{~h}, 87 \%$; b) $\mathrm{N}_{2} \mathrm{H}_{4} \cdot \mathrm{H}_{2} \mathrm{O}$, THF, $\Delta$, $16 \mathrm{~h}$; c) $\left[\mathrm{NO}_{\mathrm{x}}\right.$ ], $\mathrm{CH}_{2} \mathrm{Cl}_{2}$, r.t. $15 \mathrm{~min}, 30 \%$ (3), $10 \%$ (2) (2 steps); d) formamidine acetate, $\mathrm{N}_{2} \mathrm{H}_{4} \cdot \mathrm{H}_{2} \mathrm{O}$, EtOH, $\Delta$, 16h; e) isopentyl nitrite, $\mathrm{CH}_{2} \mathrm{Cl}_{2}$, r.t. $3 \mathrm{~h}, 42 \%$; f) $\mathrm{N}_{2} \mathrm{H}_{4} \cdot \mathrm{H}_{2} \mathrm{O}, \mathrm{MeCN}, \Delta, 16 \mathrm{~h}$.

With these model compounds in hand we were curious how these tetrazines react with simple, sterically less demanding - and less reactive - dienophiles like ethylvinyl ether (EVE). For comparison, we have used dipyridyl tetrazine $(\text { DPT })^{8}$ as standard. In order to mimic intracellular conditions, the reactions were accomplished under pseudo-first order conditions. Evaluation of the results showed that symmetrically substituted 3 and monosubstituted 1 react with EVE at comparable speeds $\left(\mathrm{k}_{2}=8\right.$ and $24 \times 10^{-3} \mathrm{M}^{-1} \mathrm{~s}^{-1}$, respectively), while compound 2 and DPT gave $\mathrm{k}_{2}$ values an order of magnitude lower. It should be noted that this order of rate constants is not in line with the reactivity order predicted by the LUMO energies (Table 1) and confirms our belief that steric demand of the substituents can also contribute to the overall reactivity.

To track down the effects of steric demand we have conducted another series of experiments where tetrazines $\mathbf{1}$ and $\mathbf{3}$ were reacted with a more reactive but bulkier dienophile $(\mathbf{C y O})^{9}$. In this case the difference in rate constants was even more profound. Monosubstituted 1 reacted ca. 30 times faster than energetically favored symmetrical tetrazine $\mathbf{3}$.
Table 1 Second order rate constants of the reaction between tetrazines and various dienophiles. The LUMO energies were calculated at the Hartree-Fock level of theory with the $6-311++\mathrm{G}^{* *}$ basis set at B3LYP/6-311++G** geometries

$\begin{array}{cccccccc}\text { tetrazine } & \begin{array}{c}\mathrm{t}_{1 / 2} \\ (\mathrm{~h})\end{array} & \begin{array}{c}\mathrm{LUMO} \\ (\mathrm{eV})\end{array} & \mathrm{EVE}^{\mathrm{a}} & \begin{array}{c}\mathrm{kyO}_{2} / \mathrm{M}^{-1} \mathrm{~s}^{-1} \\ \mathrm{COMBO}^{\mathrm{b}}\end{array} & \mathrm{TCO}^{\mathrm{b}} \\ \mathbf{D P T} & 3^{10} & 0.28 & 0.0012 & --- & --- & --- \\ \mathbf{1} & 4 & 0.71 & 0.024 & 6.25 & --- & --- \\ \mathbf{2} & 88 & 0.83 & 0.00145 & --- & 210 & 4000 \\ \mathbf{3} & 4 & 0.46 & 0.008 & 0.23 & --- & --- \\ \mathbf{4} & 6 & 0.69 & 0.010 & 2.89 & --- & --\end{array}$

a) measured in DMSO/water $(9 / 1 \mathrm{v} / \mathrm{v})$ at $25^{\circ} \mathrm{C}$; b) measured in $1 \%$ DMSO in PBS buffer (pH 7.2) at $36^{\circ} \mathrm{C}$.

To verify our findings we have also run theoretical calculations involving steric demand of reactants in transition states for the selected reactions. The geometries of the tetrazines and dienophiles as well as the corresponding transition states were optimized at the density functional (DFT) level using the B3LYP (Becke 3-parameter Lee-Yang-Parr exchangecorrelation) functional ${ }^{11}$ and the $6-311++\mathrm{G}^{* *}$ basis set. To save computer time the ethyl groups of the tetrazine derivatives were replaced by methyl groups. For each molecule considered, several stable conformers exist, which slightly differ in energy. The geometry of all conformers was optimized, and the lowest-energy one was considered in the subsequent transition state searches.

Table 2 Gibbs energies of activation $\left(\Delta \mathrm{G}^{+}, \mathrm{kcal} / \mathrm{mol}\right)$ for the reactions of tetrazines $\mathbf{1}$ and $\mathbf{3}$ with ethyl-vinyl ether and $\mathbf{C y O}$ evaluated at the B3LYP level with the $6-311++\mathrm{G}^{* *}$ basis set

\begin{tabular}{c|cc} 
Tetrazine & Ethyl-vinyl ether & CyO \\
$\mathbf{1}$ & 31.5 & 24.4 \\
$\mathbf{3}$ & 33.4 & 29.4
\end{tabular}

Furthermore, except for the reaction of 3 with EVE several transition state structures can be located. We determined the activation barriers for all the possible structures, but only the transition states with the lowest barriers are considered here. At the optimized geometries harmonic vibrational frequencies were evaluated and Gibbs energies of activation were computed in the rigid rotor-harmonic oscillator approximation. All calculations were carried out with the Gaussian 09 suite of quantum chemistry programs $^{12}$.

The results are compiled in Table 2, while in Figure 2 the transition-state geometries are visualized for the reactions of $\mathbf{1}$ and $\mathbf{3}$ with $\mathbf{C y O}$. To our delight, data are in good correlations with the experimental results. The free energies of activation are higher for compound $\mathbf{3}$ with both dienophiles. In addition, the difference between the activation barriers for the reactions of $\mathbf{1}$ and $\mathbf{3}$ is somewhat bigger for CyO. As can be seen in Figure 2 the methyl group of $\mathbf{C y O}$ is rather close to the hydrogen atom at the pyridine substitutent. Thus the 
steric repulsion is considerably stronger between the derivative substituted with the bulky pyridine group and $\mathbf{C y O}$, which explains the observed behavior of the compounds.

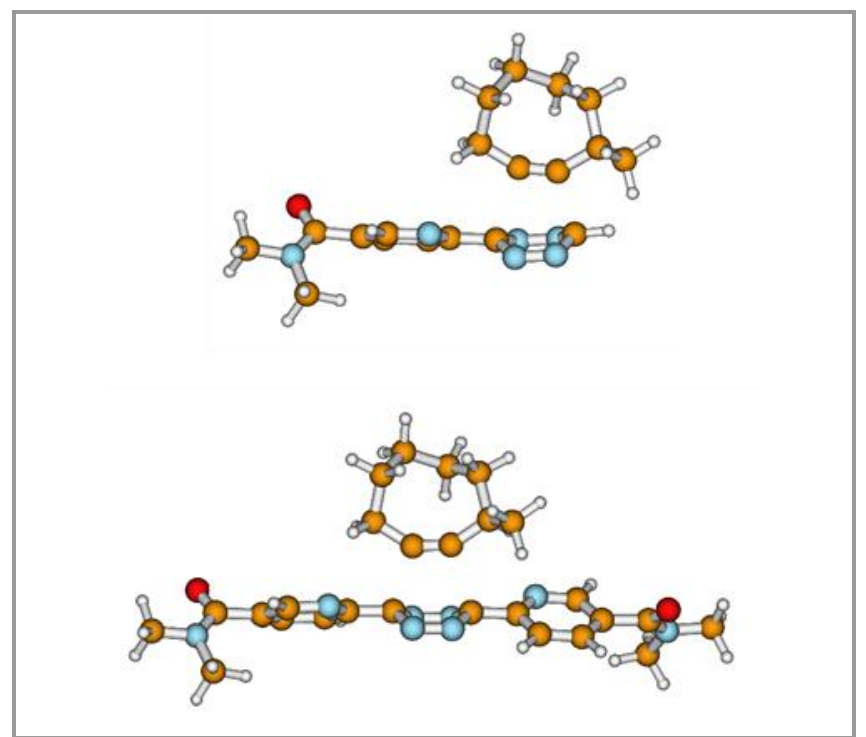

Figure 2 Optimized transition-state structures for the $\mathbf{1}+\mathbf{C y O}$ (top) and the $\mathbf{3}+\mathbf{C y O}$ (bottom) reactions.

Next we have examined the stability of the tetrazines by determining their half-lives in aqueous solutions (pH 7.2 PBS). As expected, the stability was found to be inversely proportional to reactivity. Whilst 1 reacted the fastest with all dienophiles it decomposed in aqueous solutions relatively rapidly. Tetrazine 2 on the other hand was found to be quite stable under similar conditions.

We have attempted to preserve reactivity in a more stable tetrazine scaffold. Thus we have synthesized tetrazine derivative $\mathbf{4}$ (see supporting information). We have anticipated that compound 4 would be more stable yet with comparable in reactivity to 1 . The synthesis of $\mathbf{4}$ was accomplished similarly to that of $\mathbf{1}$. Acetylation of 5-aminopicolinonitrile with acetyl chloride and subsequent reaction with formamidine acetate in the presence of hydrazine hydrate followed by oxidation with isopentyl nitrite provided model tetrazine 4 in medium yields (see supporting information). While the second order rate constant of $\mathbf{4}$ was determined to be as expected its stability turned out to be only slightly better than $\mathbf{1}$.

Our continuing efforts on DNA modification studies ${ }^{13}$ require bioorthogonal handles stable enough to survive solid phase oligonucleotide synthesis (SPOS) or stand in vivo conditions. Thus, we have sacrificed reactivity for stability and chose tetrazine $\mathbf{2}$ for further studies. To judge the reactivity of $\mathbf{2}$ we have conducted kinetic studies in the presence of highly strained and reactive dienophiles. To our delight, monobenzocyclooctyne $(\mathbf{C O M B O})^{14}$ and trans-cyclooctene $(\mathbf{T C O})^{15}$ reacted quite rapidly with 2 (Table 1) justifying its use in reasonably fast bioorthogonal labeling schemes. The reactivity of 2 with COMBO is in good accordance with similar studies with a structurally related derivative of 2 with another, less reactive strained cyclooctyne $\mathbf{B C N}^{16}\left(\mathrm{k}_{2(\mathrm{COMBO})}=210 \mathrm{M}^{-1} \mathrm{~s}^{-1}\right.$ vs. $\mathrm{k}_{2(\mathrm{BCN})}$ $\left.=80 \mathrm{M}^{-1} \mathrm{~s}^{-1}\right){ }^{17}$

Next, we aimed at incorporating non-symmetrically substituted tetrazine $\mathbf{2}$ into a deoxyuridinephosphoramidite building block. It bears the tetrazine unit linked by an aminopropynyl group at the 5position. This has two advantages: Firstly, it potentially allows to use this nucleoside conjugate for primer extension and PCR since commonly applied DNA polymerases like KlenTaq polymerase typically tolerate such modifications. ${ }^{18}$ Secondly, the structural influence by this modification should be rather small. For this, we treated cyanonicotinic acid with hydrazine hydrate in the presence of triethyl orthoacetate (Scheme 2). Subsequent oxidation with $\mathrm{NaNO}_{2} / \mathrm{HCl}$ furnished tetrazine 6. Parallel to this, commercially available 5-iodo-2'-deoxyuridine was subjected to a Sonogashira-type coupling reaction with trifluoroacetate protected propargylamine. ${ }^{13,19}$ After removal of the protecting group in aqueous ammonia the resulting amino functionalized 2'-deoxyuridine was reacted with 6 in the presence of HBTU / HOBt and Hünig's base. The tetrazine modified 2'-deoxyuridine 7 was converted to its phosphoramidite using 2-cyanoethyl- $N, N$-diisopropylchlorophosphoramidite to furnish phosphoramidite 8 (Scheme 2).

Tetrazine modified 2'-deoxyuridine phosphoramidite (8) was incorporated into a model oligonucleic acid DNA1 using standard SPOS methods. The synthetic protocol was modified such that the removal of the last DMT-protecting group from the complete sequence was followed by an automated on-bead labeling step applying a reactive cyclooctyne derivatized fluorescein dye (COMBO-Flu, Figure 3$)^{14}$ for 60 s. Mass spectrometry of the labeled oligonucleotide verified the existence of the right product. Spectrophotometric analysis of the labeled DNA showed the characteristic absorption and emission bands of fluorescein at around 500 and $520 \mathrm{~nm}$, respectively. Upon hybridization of the labeled strand with its complementary strand, DNA1c, an increase of extinction, especially of the band at $500 \mathrm{~nm}$, could be observed (see supporting information). This increase can be explained by unshielding the dye from the DNA bases upon annealing the randomly folded single stranded DNA. ${ }^{13}$ Formation of a structured double-stranded DNA presumably forced the fluorescein moiety outside the DNA-helix and face towards the more polar aqueous environment. This is supported by the melting temperatures that show only a slight decrease relative to that of the unmodified DNA $\left(56.8^{\circ} \mathrm{C}\right.$ vs. $\left.59.5^{\circ} \mathrm{C}\right)$. 


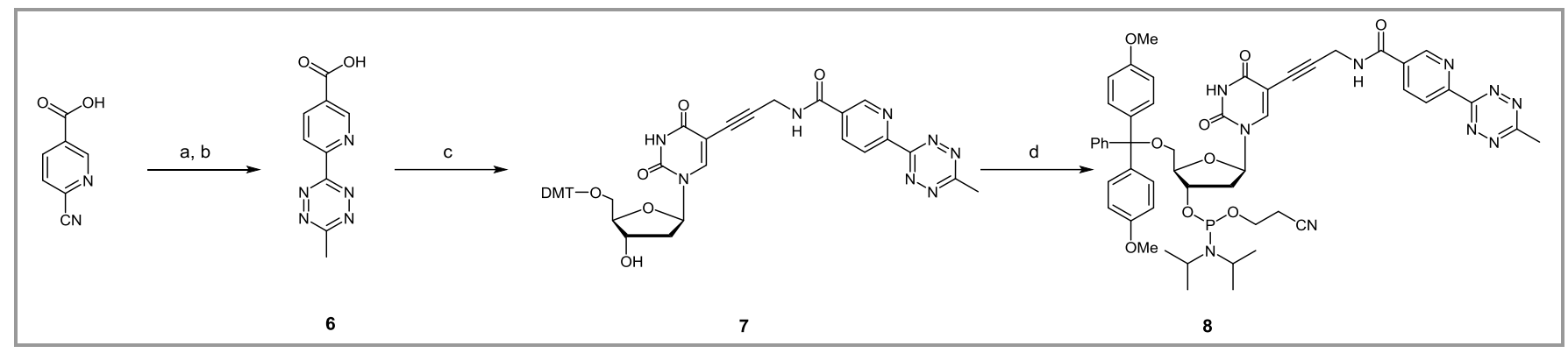

Scheme 2 Synthesis of bioorthogonalized 2'deoxyuridine-phosphoramidite 8. a) triethyl orthoacetate, $\mathrm{N}_{2} \mathrm{H}_{4} \times \mathrm{H}_{2} \mathrm{O}, \Delta, 2 \mathrm{~h} ; \mathrm{b}$ ) $\mathrm{NO}_{\mathrm{x}}, \mathrm{CH}_{2} \mathrm{Cl}$, $\mathrm{rt}$., $3 \mathrm{~h}$, 25\% (for 2 steps). c) DMT-dU-propargylamine, HBTU, HOBt, DIPEA, DMF, 16h, 65\% d) 2-cyanoethyl-N,N-diisopropylchloro phosphoramidite, DIPEA, $\mathrm{CH}_{2} \mathrm{Cl}_{2}, 89 \%$.

An on-bead labeling typically does not allow to determine yields of coupling efficiencies. However, the incorporation efficiency of the tetrazine modified building block was comparable to that of the commercial building blocks for A, G, T and C.

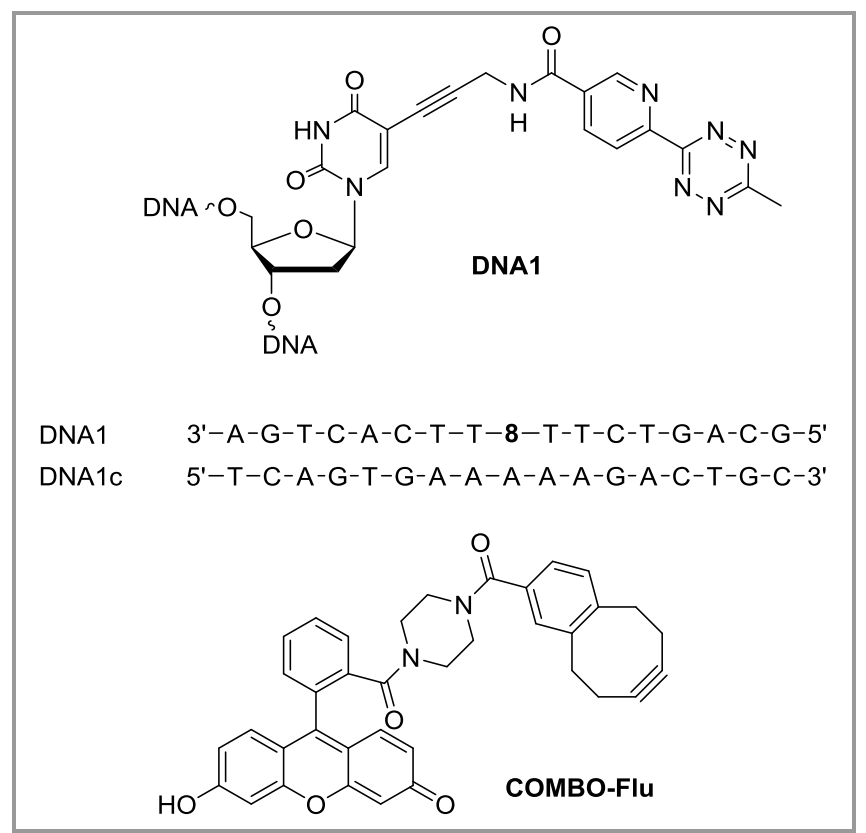

Figure 3 Sequence of DNA1 with the tetrazine building block 8 that reacts rapidly with the cycloocytyne-modified fluoresceine (COMBO-Flu).

\section{General:}

Unless otherwise indicated, all starting materials were obtained from commercial suppliers (Sigma-Aldrich, Fluka, Merck, Alfa Aesar, Reanal, Molar Chemicals) and used without further purification. Dichloromethane stabilized with ethanol was used, unless otherwise mentioned. $\mathrm{CyO}, \mathrm{COMBO}$ and $\mathrm{TCO}$ were synthesized according to literature procedures. ${ }^{9,14,15}$ Analytical thin-layer chromatography (TLC) was performed on silica gel 60 F254 precoated aluminium TLC plates from Merck. Column chromatography was carried out with flash silica gel $(0.040-0.063 \mathrm{~mm})$ from Molar Chemicals. Visualization of TLC samples was
This study revealed that steric demand of substituents play prominent role in the Diels-Alder reactivity of electron deficient tetrazines. We have investigated the reaction rates of model tetrazines in the presence of various dienophiles. The experimental findings were supported by theoretical investigations as well. Besides reactivity, the stability of these new tetrazines was also studied and it was found that only the least reactive, non-symmetrically decorated tetrazine can stand physiological conditions for longer times. For our purposes, we therefore used this scaffold in the design of a bioorthogonalized nucleic acid building block, 8 . Incorporation of this modified building block into a DNA sequence using standard solid phase nucleic acid synthesis, a fully automated protocol together with subsequent on-bead labeling experiment revealed that this tetrazine is suitable for the implementation of a reactive bioorthogonal handle into oligonucleotides.

Though in this study we have sought for stable tetrazines for incorporation into biomolecular building blocks, the more reactive tetrazines developed in this study can be used e.g. for labeling purposes where exposure times range only between $0.1-2 \mathrm{~h}$. Related labeling studies with reactive tetrazines as well as attempts to synthesize a nucleotide-triphosphate derivative of $\mathbf{8}$ in order to test the suitability of this unnatural building block in PCR applications are in progress and results will be reported in due course.

performed with a 254/365 nm UV. NMR spectra were recorded on a Bruker Avance $250 \mathrm{MHz}$, Bruker Avance III $400 \mathrm{MHz}$ or a Varian Inova $600 \mathrm{MHz}$ spectrometer. Chemical shifts $(\delta)$ are given in parts per million (ppm) using solvent signals as the reference. Coupling constants $(\mathrm{J})$ are reported in Hertz $(\mathrm{Hz})$. Splitting patterns are designated as $\mathrm{s}$ (singlet), $\mathrm{d}$ (doublet), $\mathrm{t}$ (triplet), qr (quadruplet), qv (quintuplet), m (multiplet), dd (doublet of a doublet), td (triplet doublet), dt (doublet triplet), br s (broad singlet). The exact masses were determined with an Agilent 6230 time-of-flight mass spectrometer. All melting points were measured on a Bibby Scientific SMP10 Melting Point Apparatus and are uncorrected. IR spectra were obtained on a 
Bruker Alpha-P spectrometer on a single-reflection diamond ATR unit. The fluorescence measurements were carried out on a Fluoromax 4 (Horiba) spectrofluorimeter, the UV-VIS measurements on a Cary 100 (Varian) spectrophotometer.

\section{6-cyano- $N, N$-diethylnicotinamide $(5)^{20}$}

To a solution of 6-cyanonicotinic acid $(250 \mathrm{mg}, 1.6$ mmol) in THF ( $15 \mathrm{ml})$ were added HBTU (599 mg, 1.5 $\mathrm{mmol}$ ), HOBt (257 mg, $1.6 \mathrm{mmol})$, DIPEA (604 $\mu 1,3.5$ $\mathrm{mmol})$ and diethylamine $(210 \mu \mathrm{l}, 2.0 \mathrm{mmol})$. The resulting suspension was stirred at room temperature for 12 hours. After then, the volatiles were evaporated in vacuo. Purification of the product by column chromatography on silica gel with hexanes/EtOAc 3:1 $\mathrm{v} / \mathrm{v}$ afforded $\mathbf{5}$ as a pale yellow oil in $87 \%$ yield.

${ }^{1} \mathrm{HNMR}\left(\mathrm{CDCl}_{3}\right): \delta=8.66(1 \mathrm{H}, \mathrm{d}, \mathrm{J}=1.2), 7.8(1 \mathrm{H}, \mathrm{dd}$, $\mathrm{J}=7.9,2.1), 7.7(1 \mathrm{H}, \mathrm{dd}, \mathrm{J}=7.9,0.7), 3.57-3.09(4 \mathrm{H}, \mathrm{m})$, $1.20(6 \mathrm{H}, \mathrm{m})$.

${ }^{13} \mathrm{CNMR}\left(\mathrm{CDCl}_{3}\right): \delta=171.8,147.2,138.2,131.8$, $131.3,123.2,116.2,41.9,13.15$.

\section{N,N-diethyl-6-(1,2,4,5-tetrazin-3-yl)nicotinamide (1)}

Formamidine acetate (2.95 g, $28.32 \mathrm{mmol}, 12 \mathrm{eq}$.) was dissolved in hydrazine monohydrate (aqueous 64\%, $10 \mathrm{~mL})$ and heated to $60{ }^{\circ} \mathrm{C}$. A solution of $5(0.48 \mathrm{~g}$, $2.36 \mathrm{mmol}, 1$ eq.) in anhydrous ethanol $(20 \mathrm{~mL})$ was added dropwise $(15 \mathrm{~min})$ to it and the reaction mixture was stirred overnight at $80^{\circ} \mathrm{C}$. After evaporation of the solvent the remaining sticky residue was dissolved in EtOAc $(200 \mathrm{~mL})$, washed with $10 \mathrm{~m} / \mathrm{m} \%$ citric-acid solution $(2 \times 50 \mathrm{~mL})$, cc. $\mathrm{NaHCO}_{3}$ solution $(2 \times 40 \mathrm{~mL})$ and brine $(30 \mathrm{~mL})$ and dried over $\mathrm{MgSO}_{4}$. The solution was filtered and the solvent was removed in vacuo to furnish crude dihydrotetrazine, which was dissolved in $\mathrm{CH}_{2} \mathrm{Cl}_{2}(150 \mathrm{~mL})$. Isopentyl nitrite $(950 \mu \mathrm{L}, 7.08$ mmol, 3 eq.) was added to the solution and the reaction mixture was stirred at room temperature for $3 \mathrm{~h}$ while the yellow solution turned deep red and TLC indicated the full consumption of the dihydrotetrazine. After evaporation of the solvent the crude product was purified by column chromatography $\left(\mathrm{SiO}_{2}\right.$, $\left.\mathrm{CH}_{2} \mathrm{Cl}_{2} / \mathrm{MeOH}=50 / 1 \rightarrow 30 / 1\right)$ to yield $256 \mathrm{mg} 1$ $(42 \%)$ as a purple-red solid.

T.1.c.: $\mathrm{R}_{\mathrm{f}}=0.4\left(\mathrm{CH}_{2} \mathrm{Cl}_{2} / \mathrm{MeOH}=94 / 6 \mathrm{v} / \mathrm{v}\right)$.

M.p. $=222-225{ }^{\circ} \mathrm{C}$ (decomp.).

${ }^{1} \mathrm{H}$ NMR $\left(250 \mathrm{MHz}, \mathrm{CDCl}_{3}\right) \delta=10.35(\mathrm{~s}, 1 \mathrm{H}), 8.91(\mathrm{~d}$, $\mathrm{J}=1.8 \mathrm{~Hz}, 1 \mathrm{H}), 8.70(\mathrm{~d}, \mathrm{~J}=8.1 \mathrm{~Hz}, 1 \mathrm{H}), 7.99(\mathrm{dd}, \mathrm{J}=$ $8.1,1.8 \mathrm{~Hz}, 1 \mathrm{H}), 3.56(\mathrm{q}, \mathrm{J}=6.5 \mathrm{~Hz}, 2 \mathrm{H}), 3.27(\mathrm{q}, \mathrm{J}=$ $6.5 \mathrm{~Hz}, 2 \mathrm{H}), 1.25(\mathrm{t}, \mathrm{J}=6.5 \mathrm{~Hz}, 3 \mathrm{H}), 1.14(\mathrm{t}, \mathrm{J}=6.5 \mathrm{~Hz}$, $3 \mathrm{H})$.

${ }^{13} \mathrm{C}$ NMR (62.5 MHz, $\left.\mathrm{CDCl}_{3}\right) \delta=167.4,165.2,158.3$, 150.1 148.2, 135.8, 135.6, 123.9, 43.4, 39.6, 14.2, 12.7 .

IR (neat): $v_{\max }=3074,2936,1618,1429,1344,1096$, 866.
HRMS (ESI) $[\mathrm{M}+\mathrm{H}]^{+}$calcd. for $\mathrm{C}_{12} \mathrm{H}_{15} \mathrm{~N}_{6} \mathrm{O}^{+}$: 259.1302, found: unable to acquire, decomposes.

\section{N,N-diethyl-6-(6-methyl-1,2,4,5-tetrazine-3-yl)- nicotinamide (2)}

5 (420 mg, $2.0 \mathrm{mmol}$ ) was dissolved in $\mathrm{MeCN}(20 \mathrm{ml})$. Hydrazine monohydrate (aqueous 64\%, $511 \mu \mathrm{l}, 10.25$ mmol) was added to it dropwise and the solution was stirred at $90{ }^{\circ} \mathrm{C}$ for 12 hours. The volatiles were evaporated and the residue was dissolved in $\mathrm{CH}_{2} \mathrm{Cl}_{2}$. The solution was washed twice with citric acid solution (20 mL, 5\% aqueous solution) and saturated $\mathrm{Na}_{2} \mathrm{CO}_{3}$ $(20 \mathrm{~mL})$. The organic phase was dried over $\mathrm{MgSO}_{4}$, and filtered. Nitrous gases were bubbled through the solution for 10 minutes during which time the color of the solution turned deep pink. The solvent was evaporated and the crude product was purified by column chromatography on silica gel $\left(\mathrm{CH}_{2} \mathrm{Cl}_{2} / \mathrm{MeOH}\right.$ $30: 1 \mathrm{v} / \mathrm{v})$. Further purification by recrystallization from ethanol yielded 2 as bright magenta crystals (9\%).

Melting point: $177-179{ }^{\circ} \mathrm{C}$ (decomp.).

T.1.c.: $\mathrm{R}_{\mathrm{f}}=0.3\left(\mathrm{CH}_{2} \mathrm{Cl}_{2} / \mathrm{MeOH} 30: 1 \mathrm{v} / \mathrm{v}\right)$.

${ }^{1} \mathrm{HNMR}\left(400 \mathrm{MHz}, \mathrm{CD}_{3} \mathrm{OD}\right) \delta=8.85(\mathrm{~s}, 1 \mathrm{H}), 8.75(\mathrm{~d}$, $\mathrm{J}=7.8 \mathrm{~Hz}, 1 \mathrm{H}), 8.16(\mathrm{~d}, \mathrm{~J}=7.8 \mathrm{~Hz}, 1 \mathrm{H}), 3.62(\mathrm{q}, \mathrm{J}=$ $6.4 \mathrm{~Hz}, 2 \mathrm{H}), 3.38(\mathrm{q}, \mathrm{J}=6.4 \mathrm{~Hz}, 2 \mathrm{H}), 3.13(\mathrm{~s}, 3 \mathrm{H}), 1.30$ (t, J = 6.4 Hz, 3H), $1.20(\mathrm{t}, \mathrm{J}=6.4 \mathrm{~Hz}, 3 \mathrm{H})$

${ }^{13} \mathrm{CNMR}\left(100 \mathrm{MHz}, \mathrm{CD}_{3} \mathrm{OD}\right) \delta=169.9,169.8,164.1$, $152.1,148.8,137.3,136.7,124.9,45.1,41.2,21.3$, $14.4,13.1$.

$170.3,170.1,164.6,149.3,137.8,137.2,125.3,41.8$, 22.0, $13.6 \mathrm{ppm}$.

IR (neat): $v_{\max }=2979,2967,1617,1403,1363,1285$, $867 \mathrm{~cm}^{-1}$.

${ }^{13}$ CDEPT NMR (100 MHz, $\left.\mathrm{CDCl}_{3}\right): \delta=169.9(-)$, 169.8(-), 164.1(-), 152.1(-), 148.8(+), 137.3(+), 136.7(), 124.9(+), 45.1(-), 41.2(-), 21.3(+), 14.4(+), 13.1(+).

HRMS (ESI) $[\mathrm{M}+\mathrm{Na}]^{+}$calcd. for $\mathrm{C}_{13} \mathrm{H}_{16} \mathrm{~N}_{6} \mathrm{ONa}^{+}$: 295.1283, found: 295.1295 .

\section{6,6'-(1,2,4,5-tetrazine)-bis( $N, N$-diethylnicotinamide)}

(3)

5 (297 mg, $1.4 \mathrm{mmol}$ ) was dissolved in $10 \mathrm{ml}$ THF. Aqueous hydrazine monohydrate $(64 \%, 141 \mu 1,2.93$ mmol) was added dropwise and the solution was stirred at $80{ }^{\circ} \mathrm{C}$ overnight. The THF was evaporated and the resulting crude dihydrotetrazine was redissolved in 150 $\mathrm{ml}$ of $\mathrm{CH}_{2} \mathrm{Cl}_{2}$ and oxidized directly with nitrous gases. The nitrous gases were bubbled through the stirred solution for 10 minutes. After evaporation of $\mathrm{CH}_{2} \mathrm{Cl}_{2}$ the crude product was purified by column chromatography on silica gel $\left(\mathrm{CH}_{2} \mathrm{Cl}_{2} / \mathrm{MeOH}\right.$ $94: 6 \mathrm{v} / \mathrm{v})$. Further purification is possible by recrystallization from EtOAc to yield $\mathbf{3}$ as magenta crystals $(30 \%)$.

T.1.c.: $\mathrm{R}_{\mathrm{f}}=0.7\left(\mathrm{CH}_{2} \mathrm{Cl}_{2} / \mathrm{MeOH} 94: 6 \mathrm{v} / \mathrm{v}\right)$. 
M.p.: $180-183{ }^{\circ} \mathrm{C}$ (decomp.).

${ }^{1} \mathrm{HNMR}\left(400 \mathrm{MHz}, \mathrm{CDCl}_{3}\right): \delta=8.98(\mathrm{~d}, \mathrm{~J}=1.4 \mathrm{~Hz}$, $2 \mathrm{H}), 8.81(\mathrm{~d}, \mathrm{~J}=8.2 \mathrm{~Hz}, 2 \mathrm{H}), 8.04(\mathrm{dd}, \mathrm{J}=8.2,1.4 \mathrm{~Hz}$, $2 \mathrm{H}), 3.61(\mathrm{q}, \mathrm{J}=6.3 \mathrm{~Hz}, 4 \mathrm{H}), 3.33(\mathrm{q}, \mathrm{J}=6.3 \mathrm{~Hz}, 4 \mathrm{H})$, $1.40-1.10(\mathrm{~m}, 12 \mathrm{H})$.

${ }^{13} \mathrm{CNMR}\left(100 \mathrm{MHz}, \mathrm{CDCl}_{3}\right): \delta=167.7,163.6,150.4$, 148.6, 136.0, 135.8, 124.5, 43.6, 39.9, 14.5, 13.0.

IR (neat): $v_{\max }=1629,1427,1362,1290,1124,857$, $603 \mathrm{~cm}^{-1}$.

${ }^{13}$ CDEPT NMR (100 MHz, $\left.\mathrm{CDCl}_{3}\right): \delta=167.7(-)$, $163.6(-), \quad 150.4(-), \quad 148.6(+), \quad 136.0(+), \quad 135.8(-)$, 124.5(+), 43.6(-), 39.9(-), 14.5(+), 13.0(+).

HRMS (ESI) $[\mathrm{M}+\mathrm{Na}]^{+}$calcd. for $\mathrm{C}_{22} \mathrm{H}_{26} \mathrm{~N}_{8} \mathrm{O}_{2} \mathrm{Na}^{+}$: 457.2076, found: 457.2092.

\section{6-(6-methyl-1,2,4,5-tetrazin-3-yl)nicotinic acid (6)}

6-cyanonicotinic acid (593 mg, $4.00 \mathrm{mmol}, 1$ eq.), sulfur (90 mg, $2.80 \mathrm{mmol}, 0.7$ eq.) and triethyl orthoacetate $(18.3 \mathrm{~mL}, 100 \mathrm{mmol}, 25$ eq.) was placed in a round bottomed flask and flushed with $\mathrm{N}_{2}$. Hydrazine monohydrate $(15 \mathrm{~mL}, 300 \mathrm{mmol}, 75$ eq.) was added and the reaction mixture was stirred vigorously at $100{ }^{\circ} \mathrm{C}$ for $2 \mathrm{~h}$. After cooling to room temperature the solution was diluted with EtOAc (200 $\mathrm{mL}$ ) and washed with $10 \mathrm{~m} / \mathrm{m} \%$ citric-acid solution $(2 \times 75 \mathrm{~mL})$, cc. $\mathrm{NaHCO}_{3}$ solution $(2 \times 50 \mathrm{~mL})$, brine $(30 \mathrm{~mL})$ and dried over $\mathrm{MgSO}_{4}$. The solution was filtered and the solvent was evaporated. Crude dihydrotetrazine was suspended in $\mathrm{CH}_{2} \mathrm{Cl}_{2}(150 \mathrm{~mL})$ and oxidized with in situ generated nitrous gases $\left(\mathrm{NO}_{\mathrm{x}}\right)$ till t.l.c. indicated the consumption of all dihydrotetrazine and the solution turned deep red. After evaporation of the solvent the crude product was purified by column chromatography $\left(\mathrm{SiO}_{2}\right.$, $\left.\mathrm{CH}_{2} \mathrm{Cl}_{2} / \mathrm{MeOH}=9 / 1 \mathrm{v} / \mathrm{v}\right)$ to yield $218 \mathrm{mg} 6(25 \%)$ as a purple-red solid.

T.1.c.: $\mathrm{R}_{\mathrm{f}}=0.2\left(\mathrm{CH}_{2} \mathrm{Cl}_{2} / \mathrm{MeOH}=10 / 1 \mathrm{v} / \mathrm{v}\right)$.

M.p. $=158-161{ }^{\circ} \mathrm{C}$ (decomp.).

${ }^{1} \mathrm{HNMR}(250 \mathrm{MHz}$, DMSO-d 6 ) $\delta=9.33(\mathrm{dd}, \mathrm{J}=2.1$, $0.7 \mathrm{~Hz}, 1 \mathrm{H}), 8.64(\mathrm{dd}, \mathrm{J}=8.2,0.7 \mathrm{~Hz}, 1 \mathrm{H}), 8.56(\mathrm{dd}, \mathrm{J}$ $=8.2,2.1 \mathrm{~Hz}, 1 \mathrm{H}), 3.06(\mathrm{~s}, 3 \mathrm{H})$.

${ }^{13} \mathrm{CNMR}\left(150 \mathrm{MHz}, \mathrm{DMSO}-\mathrm{d}_{6}\right) \delta=167.7,165.9$, 162.7, 153.2, 150.8, 138.5, 128.6, 123.7, 21.0.

MS (ESI): [M-H]- calcd. for $\mathrm{C}_{9} \mathrm{H}_{6} \mathrm{~N}_{5} \mathrm{O}_{2}^{-}: 216.1$, found: 216.0.

IR(neat): $v_{\max }=3051,2850,2552,1680,1402,1247$, 1020 .

HRMS (ESI) $[\mathrm{M}+\mathrm{Na}]^{+}$calcd. for $\mathrm{C}_{9} \mathrm{H}_{7} \mathrm{~N}_{5} \mathrm{O}_{2} \mathrm{Na}^{+}$: 240,0492, found: 240.0484 .

$N-(3-(1-((2 R, 4 S, 5 R)-5-((b i s) 4-$

methoxyphenyl)(phenyl)methoxy)methyl)-4-

hydroxytetrahydrofuran-2-yl)-2,4-dioxo-1,2,3,4-

tetrahydropyrimidin-5-yl)prop-2-yn-1-yl)-6-(6-methyl1,2,4,5-tetrazin-3-yl)nicotinamide (7)
In a round bottom flask $6(56 \mathrm{mg}, 0.26 \mathrm{mmol}, 1 \mathrm{eq})$ HBTU (107 mg, $0.28 \mathrm{mmol}, 1.1 \mathrm{eq})$ and HOBt (3.94 $\mathrm{mg}, \quad 0.03 \mathrm{mmol}, 0.1 \mathrm{eq}$ ) were dried in vacuиo overnight. In a separate flask DMT-protected propargylamino modified deoxyuridine $(150 \mathrm{mg}$, $0.26 \mathrm{mmol}, 1 \mathrm{eq}$ ) was also dried overnight in vacuo. The mixture of $\mathbf{6}$, HBTU and HOBt was dissolved in $5 \mathrm{~mL}$ of dry DMF and was stirred for $15 \mathrm{~min}$. Subsequently $60 \mu \mathrm{L}$ DIPEA $0.35 \mathrm{mmol}, 1.35 \mathrm{eq}$ ) were added and the solution was stirred for another $15 \mathrm{~min}$. The DMT-protected propargylamino-deoxyuridine was also dissolved in $2 \mathrm{~mL}$ of dry DMF and added to the first solution, and the resulting mixture was stirred overnight at room temperature. The solvent was removed under reduced pressure at $40{ }^{\circ} \mathrm{C}$ and the residue was purified by column chromatography $\left(\mathrm{SiO}_{2}\right.$, $\mathrm{CH}_{2} \mathrm{Cl}_{2} / \mathrm{MeOH} 30 / 1 \mathrm{v} / \mathrm{v}+0.1 \%$ DIPEA) to furnish 7 in $65 \%$ yield.

T.l.c.: $\mathrm{R}_{\mathrm{f}}=0.3\left(\mathrm{CH}_{2} \mathrm{Cl}_{2} / \mathrm{MeOH} 15 / 1 \mathrm{v} / \mathrm{v}\right)$.

${ }^{1} \mathrm{HNMR}\left(300 \mathrm{MHz}, \mathrm{DMSO}-\mathrm{d}_{6}\right): \delta=11.70(1 \mathrm{H}, \mathrm{s}), 9.38$ $(1 \mathrm{H}, \mathrm{t}, \mathrm{J}=5.0), 9.28(1 \mathrm{H}, \mathrm{m}), 8.61(1 \mathrm{H}, \mathrm{d}, \mathrm{J}=8.2), 8.49$ $(1 \mathrm{H}, \mathrm{d}, \mathrm{J}=8.2), 7.94(1 \mathrm{H}, \mathrm{s}), 7.30(9 \mathrm{H}, \mathrm{m}), 6.89(4 \mathrm{H}$, $\mathrm{m}), 6.10(1 \mathrm{H}, \mathrm{t}, \mathrm{J}=6.3), 5.34(1 \mathrm{H}, \mathrm{d}, \mathrm{J}=4.4), 4.27(1 \mathrm{H}$, $\mathrm{m}), 4.22(2 \mathrm{H}, \mathrm{d}, \mathrm{J}=5.5), 3.92(1 \mathrm{H}, \mathrm{m}), 3.72(6 \mathrm{H}, \mathrm{s})$, $3.25(2 \mathrm{H}, \mathrm{m}), 3.06(3 \mathrm{H}, \mathrm{s}), 2.25(2 \mathrm{H}, \mathrm{m})$.

${ }^{13} \mathrm{C}-\mathrm{NMR}(100 \mathrm{MHz}$, DMSO-d 6$)=167.75,163.9$, $162.9,161.7,158.1,152.35,149.4,149.3,144.8,143.5$, $136.85,135.7,135.2,131.2,129.8,129.7,128.4,127.0$, $128.58,123.45,113.3,98.3,89.1,85.9,85.1,74.5$, $70.5,63.8,55.1,53.6,45.8,41.9,29.5,21.1,18.1,16.8$, 12.6, 8.7.

HRMS (ESI) $[\mathrm{M}+\mathrm{H}]^{+}$calcd. for: $\mathrm{C}_{42} \mathrm{H}_{39} \mathrm{~N}_{8} \mathrm{O}_{8}{ }^{+}$: 783.2884, found: 783.2885 .

\section{$(2 R, 3 S, 5 R)-2-((b i s(4-$}

methoxyphenyl)(phenyl)methoxy)methyl)-5-(5-(3-(6(6-methyl-1,2,4,5-tetrazin-3-yl)nicotinamido)prop-1yn-1-yl)-2,4-dioxo-3,4-dihydropyrimidin-1 $(2 \mathrm{H})$ -

yl)tetrahydrofuran-3-yl diisopropylphosphoramidite (8)

(2-cyanoethyl)

In a round bottom flask under argon atmosphere $80 \mathrm{mg}$ 7 ( $80 \mathrm{mg}, 102 \mu \mathrm{mol}, 1 \mathrm{eq}$ ) was dissolved in $2 \mathrm{~mL}$ abs. $\mathrm{CH}_{2} \mathrm{Cl}_{2}$ and $36.7 \mu \mathrm{L}$ DIPEA $(200 \mu \mathrm{mol}, 2 \mathrm{eq})$ was added. To this solution 2-cyanoethyl- $N, N$ diisopropylchloro phosphoramidite $(34.2 \mu \mathrm{L}$, $153 \mu \mathrm{mol}, 1.5 \mathrm{eq})$ was added and the reaction was stirred for $1.5 \mathrm{~h}$ at room temperature. The reaction mixture was directly taken onto the chromatography column to elute the product very fast $\left(\mathrm{SiO}_{2}\right.$, $\mathrm{CH}_{2} \mathrm{Cl}_{2} /$ Aceton $3 / 2 \mathrm{v} / \mathrm{v}+0.1 \%$ DIPEA). Evaporation of the solvent in vacuo and the resulting pink solid was lyophilized with benzene to obtain 8 in $89 \%$ yield.

T.1.c.: $\mathrm{R}_{\mathrm{f}}=0.8\left(\mathrm{CH}_{2} \mathrm{Cl}_{2} /\right.$ Acetone $\left.3 / 2 \mathrm{v} / \mathrm{v}\right)$.

${ }^{31}$ PNMR (101 MHz, DMSO-d 6 ); $\delta=150.07,149.67$. HRMS (ESI) $[\mathrm{M}+\mathrm{H}]^{+}$calcd. for: $\mathrm{C}_{51} \mathrm{H}_{56} \mathrm{~N}_{10} \mathrm{O}_{9} \mathrm{P}^{+}$: 983.3964 found: 983.3962 . 
Supporting Information for this article is available online at http://www.thiemeconnect.com/products/ejournals/journal/10.1055/s00000084.

Primary Data for this article are available online at http://www.thieme-

connect.com/products/ejournals/journal/10.1055/s00000084 and can be cited using the following DOI: (number will be inserted prior to online publication). If Primary Data are not being supplied for this manuscript, please delete this paragraph.

\section{Acknowledgment}

Financial support of the Deutsche Forschungsgemeinschaft (ERACHEM Wa 1386/16-1), the KIT, the Hungarian Scientific Research Fund (OTKA-NN 110214) and the "Lendület" Program of the Hungarian Academy of Sciences (LP201355/2013 and LP2013-64/2013) is greatly acknowledged. We also thank Dr. Balázs Varga for synthetizing the fluorescent probe.

\section{References}

(1) Knall, A.-C.; Slugovc, C. Chem. Soc. Rev. 2013, 42, 5131.

(2) Bußkamp, H.; Batroff, E.; Niederwieser, A.; AbdelRahman, O. S.; Winter, R. F.; Wittmann, V.; Marx, A. Chem. Commun. 2014, 50, 10827.

(3) Rieder, U.; Luedtke, N. W. Angew. Chem. Int. Ed. 2014, $53,9168$.

(4) (a) Schoch, J.; Ameta, S.; Jäschke, A. Chem. Commun 2011, 47, 12356. (b) Asare-Okai, P. N.; Augustin, E.; Fabris, D.; Royzen, M. Chem. Commun. 2014, 50, 7844. (c) Pyka, A. M.; Domnick, C.; Braun, F.; Kath-Schorr S. Bioconjugate Chem. 2014, 25, 1438. (d) Ameta, S.; Becker, J.; Jäschke, A. Org. Biomol. Chem. 2014, 12, 4701.

(5) Nikić, I.; Plass, T.; Schraidt, O.; Szymański, J.; Briggs, J. A.; Schultz, C.; Lemke, E. A. Angew. Chem. Int. Ed. 2014, 53, 2245.

(6) Schoch, J.; Staudt, M.; Samanta, A.; Wiessler, M.; Jäschke, A. Bioconjugate Chem. 2012, 23, 1382.

(7) Wijnen, J.; Zavarise, S.; Engberts, J.; Charton, M. J. Org. Chem. 1996, 61, 2001.

(8) Geldard, J.; Lions, F. J. Org. Chem. 1965. 30, 318.

(9) Agard, N.; Baskin, J.; Prescher, J.; Lo, A.; Bertozzi, C. ACS Chem. Biol. 2006, 1, 644.

(10) Hoeben, F. J. M.; Robillard, M. S.; Rossin, R.; Ten, H. W.; Versteegen, R. M. PCT Int. Appl. WO 2012156920.

(11) Becke, A. J. Chem. Phys., 1993, 98, 5648.

(12) Gaussian 03, Revision B.01, Frisch, M. J. et al., Gaussian, Inc., Pittsburgh PA, 2003.

(13) Stubinitzky, C.; Cserép, G. B.; Bätzner, E.; Kele, P.; Wagenknecht, H.-A. A. Chem. Commun. 2014, 50, 11218 .

(14) Varga, B. R.; Kállay, M.; Hegyi, K.; Béni, S.; Kele, P. Chemistry 2012, $18,822$.

(15) Royzen, M.; Yap, G.; Fox, J. J. Am. Chem. Soc. 2008. 130,3760 .

(16) Dommerholt, J.; Schmidt, S.; Temming, R.; Hendriks, L.; Rutjes, F.; Hest, J. van; Lefeber, D.; Friedl, P.; van Delft, F. Angew. Chem. Int. Ed. 2010, 49, 9422.

(17) Lang, K.; Davis, L.; Wallace, S.; Mahesh, M.; Cox, D.; Blackman, M.; Fox, J.; Chin, J. J. Am. Chem. Soc. 2012, 134, 10317.
(18) Bergen, K.; Steck, A.-L.; Schütt, S.; Baccaro, A.; Welte, W.; Diederichs, K.; Marx, A. J. Am. Chem. Soc. 2012, $134,11840$.

(19) (a) Battersby, T.; Ang, D.; Burgstaller, P.; Jurczyk, S.; Bowser, M.; Buchanan, D.; Kennedy, R.; Benner, S. J. Am. Chem. Soc. 1999, 121, 9781. (b) Brazier, J. A.; Shibata, T.; Townsley, J.; Taylor, B. F.; Frary, E.; Williams N. H.; Williams, D. M. Nucleic Acids Res., 2005, 33, 1362. (c) Nuzzolo, M.; Grabulosa, A.; Slawin, A.; Meeuwenoord, N.; Marel, G.; Kamer, P. Eur. J. Org. Chem. 2010, 3229.

(20) Sakamoto, T.; Kaneda, S-I.; Nishimura, S.; Yamanaka, H. Chem. Pharm. Bull. 1985, 33, 565. 
Please place the graphical abstract and short title of the article here. The short title will be used as a running header.

\section{Activation or free approach?}

Energetically more favored

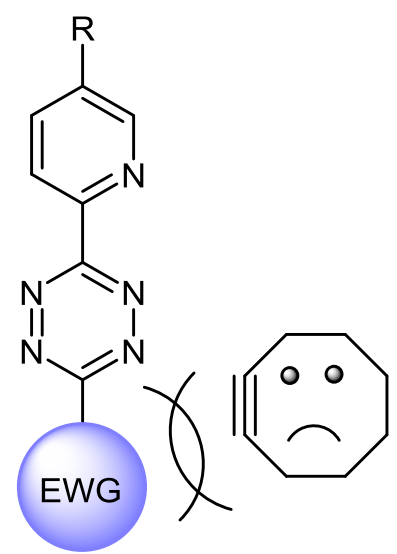

Steric hindrance
Energetically less favored<smiles>[R]c1ccc(-c2nncnn2)nc1</smiles>

No hindrance

\section{Manuscript submission checklist}

- Statement of significance of work.

- Full mailing address, telephone, and fax numbers and e-mail address of the corresponding author.

- Graphical abstract.

- 5 key words.

- Original Word file.

- Original graphics files.

Proceed to submit your article via our online submission system at http://mc.manuscriptcentral.com/synthesis. When prompted to "Add an Editor", please select the Editor who invited you to submit this Special Topic article. 